\title{
A COLABORAÇÃO PREMIADA \\ E O LEGADO INQUISITORIAL NO PROCESSO PENAL BRASILEIRO*
}

\author{
Paulla Leite** \\ Felipe Lazzari da Silveira***
}

\section{RESUMO}

O presente trabalho trata da colaboração premiada e os possíveis resquícios de práticas inquisitoriais quando de sua aplicação. 0 instituto consiste na cooperação do acusado ou suspeito com as investigações criminais, especialmente fornecendo informações acerca da estrutura organizacional e identificação dos demais coautores e partícipes da organização criminosa, em troca de benesses negociadas com o Estado. Sua utilização desmedida gera controvérsias no mundo jurídico, sobretudo em razão da importância que vem ganhando no âmbito da Operação Lava Jato e que envolve grandes nomes do cenário político e econômico do país. Assim, a partir da análise do sistema inquisitorial e do instituto da colaboração premiada, pretende-se delinear um paralelo entre ambas, objetivando fomentar a discussão sobre o tema em face da necessidade de aprimoramento da legislação.

Palavras-chave: Processo Penal. Inquisição. Colaboração Premiada.

* Artigo apresentado ao Curso de Bacharelado em Direito do Centro Universitário Metodista - IPA, como requisito parcial para obtenção do Grau de Bacharel em Direito.

** Graduanda do Curso de Bacharelado em Direito do Centro Universitário Metodista - IPA.

*** Orientador: Prof. Me. Felipe Lazzari da Silveira. Professor de Direito Penal e Processo Penal do Centro Universitário Metodista - IPA. 


\section{THE PLEA BARGAINING AND THE INQUISITORIAL LE- GACY IN THE BRAZILIAN CRIMINAL PROCEEDINGS}

\section{ABSTRACT}

The present work deal with the plea bargaining and possible remnants of inquisitorial practices when applied. The institute consists in the cooperation of the accused or suspect with criminal investigations, especially providing information about the organizational structure and identification of the other co-authors and participants of the criminal organization, in exchange for negotiated benefits with the State. Its excessive use generates controversies in the legal world, mainly due to the importance it has been gaining in the scope of Operation Car Wash and which involves great names of the political and economic scenario of the country. Thus, from the analysis of the inquisitorial system and the institute of the plea bargaining, it is intended to delineate a parallel between both, aiming to foment the discussion on the subject in the face of the need for improvement of the legislation.

Key words: Criminal Proceedings. Inquisition. Plea Bargaining.

\section{INTRODUÇÃO}

0 presente trabalho tem como tema o legado inquisitorial no instituto da colaboração premiada no processo penal brasileiro. Considerando o cenário atual brasileiro, sobretudo as críticas que o instituto vem recebendo dos especialistas no tema, questiona-se se a colaboração premiada, do modo como é prevista no ordenamento jurídico e está sendo operada, pode ser interpretada como uma herança inquisitorial no sistema de justiça criminal brasileiro.

Embora existente em nosso ordenamento jurídico atual democrático desde a entrada em vigor da Lei 8.072/1.990 (Lei dos Crimes Hediondos), o instituto da colaboração premiada, instituído pela Lei 12.850/2013 (Lei de Combate às Organizações Criminosas), tem gerado grandes repercussões e divergências entre juristas brasileiros em decorrência da notoriedade que se tem dado ao tema devido aos constantes acordos celebrados nos 
processos de crimes de corrupção e lavagem de dinheiro, sobretudo no âmbito da Operação Lava Jato, que se tornou uma das mais importantes já realizadas no Brasil envolvendo importantes nomes do cenário político e econômico atual.

Nesse sentido, o objetivo do presente trabalho é identificar em que medida o instituto da colaboração premiada, do modo como é previsto na legislação e vem sendo aplicado no exercício da jurisdição, pode ensejar a reativação dos paradigmas inquisitoriais no processo penal brasileiro. Aparentemente, tais práticas estão sendo utilizadas de forma desmedida com o intuito de buscar a verdade dos fatos, o que pode estar gerando abusos na sua aplicação.

Inicialmente, pretende-se fazer uma análise das práticas inquisitoriais que remontam à Idade Média, após, verificar a evolução do instituto da delação/colaboração premiada no ordenamento jurídico brasileiro e analisar aspectos relevantes para o desenvolvimento do tema, e, por fim, traçar um paralelo entre ambas, com o objetivo de fomentar a discussão sobre o assunto, que se mostra de grande relevância no cenário processual penal atual, bem como no cenário politico. Por um lado, é necessária a existência, no processo penal, de mecanismos eficazes para o desmantelamento das organizações criminosas, a fim de estancar a continuidade da prática desses delitos que atingem de forma sistemática o país nos dias de hoje e, por conseguinte, a população brasileira como um todo. De outro lado, não se pode olvidar que a todos os acusados são conferidos direitos e garantias fundamentais que asseguram a tramitação democrática do processo.

O que se almeja com o presente artigo é identificar se a previsão legal do instituto da colaboração premiada e a forma com que os acordos vêm sendo celebrados possuem algum resquício das práticas inquisitoriais, operadas principalmente pela Igreja Católica no combate à heresia, entre os séculos XIII e XVIII. Tal estudo mostra-se de grande relevância na medida em 
que a temática merece maiores discussões no mundo jurídico em busca do aprimoramento da legislação e de sua utilização, em razão da complexidade e grande aplicabilidade no processo penal brasileiro atual.

\section{BREVES APONTAMENTOS SOBRE O SISTEMA PROCESSUAL INQUISITORIAL}

Desde que o homem começou a viver coletivamente surgiu a necessidade de criar uma estrutura organizada para que a vida em sociedade pudesse prosperar, com fins de garantir o bem-estar de todos. Essa organização se deu em forma de Estado, que passou a elaborar as leis a fim de estabelecer normas de condutas para regular e disciplinar as relações entre os homens, inclusive dispondo sobre as consequências que poderiam advir de seu descumprimento, sendo o único detentor do poder de punir (jus puniendi) aqueles que agissem em desconformidade com tais normas. A maneira que o Estado criou de dirimir os conflitos de interesse foi por meio do processo, que nada mais é que uma sucessão de atos coordenados com a finalidade de solucionar um litígio, aplicando a lei no caso concreto.

No âmbito penal, conforme ensina Tourinho Filho, ${ }^{1}$ o processo pode ser observado já dentre as primeiras civilizações. De um modo geral, os crimes eram divididos entre públicos, que eram aqueles que prejudicavam toda a coletividade, e privados, considerados de menor importância para o Estado, atuante apenas como árbitro, e, por isso, sua repressão dependia da exclusiva iniciativa da parte. 0 sistema acusatório da Grécia antiga, de onde é originário, caracterizava-se pela participação direta do povo no exercício da acusação (qualquer cidadão podia formular a acusação diante do oficial competente) e da jurisdição, sendo o julgamento feito de forma oral e pública. Existia certa igualda-

TOURINHO FILHO, Fernando da Costa. Processo penal. v. 1. 29. ed. rev. atual. São Paulo: Saraiva, 2007. p. 79. 
de entre acusador e acusado uma vez que havia a necessidade de o acusado defender-se, como uma espécie de contraditório. Contudo, as sanções aplicadas a quem fosse considerado culpado eram extremamente cruéis, desconsiderando quaisquer direitos do indivíduo perante o Estado, a fim de beneficiar o todo. Assim, o processo penal surge como meio de limitar o jus puniendi do Estado, já que único possuidor desse poder.

Em Roma, é possível notar que as diferentes formas de organização política influenciaram diretamente o processo penal. $\mathrm{Na}$ cognitio, praticada no período da Monarquia, não havia limites ao poder de julgar. Não era necessária uma acusação, o próprio magistrado iniciava as investigações diante de uma noticia criminis, impondo a pena a seu livre arbítrio, sem nenhuma garantia ao acusado. A provocatio ad populum surgiu como uma forma de limitar o poder (quase que absoluto) do Juiz, em que o condenado poderia recorrer ao povo para a prolação de uma nova decisão; contudo, tal benesse somente era concedida aos civis romanos, parcela restrita da população. Já durante a República surge a accusatio, uma forma de processo que se dava mediante provocação, através da figura do acusador, conferida a qualquer cidadão, que, uma vez aceita a acusação pelo magistrado, procedia às investigações, submetendo o julgamento ao Tribunal popular, cabendo ao juiz manter a ordem e lavrar a sentença. Se o acusador apresentasse fatos falsos, incorria no crime de calúnia, sendo punido por tal. ${ }^{2}$

Durante a época do Império, em função das necessidades do novo regime político, surge a cognitio extra ordinem. Como a acusação era feita pelos cidadãos no sistema anterior, muitos restavam inertes, indiferentes, resultando em muitos delitos impunes. Dessa forma, o que era considerado uma honra (ser acusador) converteu-se em maldade, uma vez que recompensas eram prometidas aos delatores, que acabavam por extorquir os

2 Idem. p. 81. 
acusados. Assim, segundo ensinamentos de Khaled Jr., ${ }^{3}$ no novo sistema nasce a figura do acusador oficial, funcionários que atuavam por iniciativa própria ou através de denúncia anônima, encarregados de investigar os acusados secretamente. Em um segundo momento, os magistrados passaram a atuar de ofício, reunindo as funções de acusar e julgar na figura do Estado. Além disso, o procedimento extraordinário introduziu a tortura no processo penal romano. De início torturava-se o réu e, depois, não só o réu como também as testemunhas para que falassem a verdade. Aponta Lopes Jr., que "nesse momento começam a surgir as primeiras características do que viria a ser considerado como um sistema: o inquisitório". ${ }^{4}$

Dentre os povos germânicos, como bem lembra Tourinho Filho, ${ }^{5}$ nos processos dos crimes públicos, cabia ao acusado provar sua inocência, sendo que a confissão já era resultado de condenação. Caso jurasse ser inocente, o réu era submetido ao Juízo de Deus, que realizava o duelo judicial, conferindo à divindade a decisão, e somente seria absolvido se sobrevivesse a um "milagre", como sair ileso a uma imersão em água fervente. Acreditavam que os deuses intervinham no processo a favor da parte que tinha razão.

Ainda segundo Tourinho Filho, ${ }^{6}$ com a invasão de Roma pelos germânicos, alguns desses costumes permaneceram. No final do Império Romano, com a expansão do cristianismo e do pensamento religioso, a Igreja Católica passa a exercer o controle político sobre grande parte da Europa Continental durante a Idade Média. Assim, a prática dos Juízos de Deus passou a exigir

3 KHALED JR., Salah H. A busca da verdade no processo penal: para além da ambição inquisitorial. 2. ed. Belo Horizonte, MG: Letramento: Casa do Direito, 2016, p. 48.

4 LOPES JR., Aury. Direito Processual Penal e sua Conformidade Constitucional. v. 1. 3. ed. Rio de Janeiro: Lumen Juris, 2008, p. 58.

5 TOURINHO FILHO, Fernando da Costa. Op.cit. 2007. p. 83-84.

6 Idem. p. 84. 
a presença de um representante da Igreja. Nesse contexto, o processo penal canônico contribuiu de forma definitiva para delinear as características do modelo inquisitorial.

Até o século XII o processo era essencialmente acusatório, sendo imprescindível a figura de um acusador legítimo e idôneo. Em linhas gerais, são "características nitidamente acusatórias: separação das funções de acusar e julgar, juiz alheio à gestão da prova, publicidade e oralidade".7

A partir do século XIII começa a estabelecer-se o sistema inquisitório, quando, em 1215, o Concílio de Latrão considerou que ao processo bastavam os suspeitos, sendo desnecessária a figura do acusador, regrando, inclusive, a confissão dos pecados como obrigatória em busca da "verdade". Em 1252, o Papa Inocêncio IV editou a bula Ad extripanda a qual institucionalizou o Tribunal da Inquisição e autorizou o uso da tortura para obtenção da confissão pelos hereges. Assim, o sistema inquisitorial foi introduzido em diversos países da Europa Continental como um instrumento de dominação política. Para Lopes Jr., o sistema inquisitório mudou radicalmente a cara do processo penal:

\footnotetext{
0 que era um duelo leal e franco entre acusador e acusado, com igualdade de poderes e oportunidades, se transforma em uma disputa desigual entre o juiz-inquisidor e o acusado. 0 primeiro abandona sua posição de árbitro imparcial e assume a atividade de inquisidor, atuando desde o início também como acusador. Confundem-se as atividades do juiz e acusador, e o acusado perde a condição de sujeito processual e se converte em mero objeto de investigação. ${ }^{8}$
}

Inicialmente, cabe apontar as características gerais do sistema inquisitorial. Nesse modelo processual o réu desconhecia

KHALED JR, Salah H. Op.cit. 2016, p. 56.

8 LOPES JR, Aury. Op.cit. 2008, p. 61. 
a existência do processo contra ele, o juiz procedia de ofício e em segredo, inclusive a tomada de depoimento das testemunhas. Uma simples denúncia era suficiente para se iniciar o processo. Conforme ensinamentos de Lopes Jr., ${ }^{9}$ o juiz atuava como parte, investigava, dirigia, acusava e julgava. Nenhuma garantia era dada ao acusado, tampouco lhe era permitida a defesa, pois essa poderia criar obstáculos na descoberta da verdade, não existindo, portanto, o contraditório. Não existia igualdade entre as partes, pois o acusado não passava de objeto de investigação, logo, não era um sujeito de direito.

As práticas utilizadas pelos inquisidores foram reunidas em vários manuais. Dentre eles, o inquisidor Nicolau Eymerich, em 1376, relatou o modelo inquisitório do Direito Canônico no Directorium Inquisitorum (tradução brasileira sob o título Manual dos Inquisidores) ${ }^{10}$ revisto e ampliado por Francisco Peña em 1578 , onde é possível encontrar conceitos e normas processuais a serem seguidas pelos inquisidores, incluindo termos e modelos de sentença, tudo voltado para a busca da verdade absoluta, legitimando ainda mais a tortura e a crueldade dentro do sistema inquisitorial daquela época.

Além de Eymerich, outros inquisidores disciplinaram diversas atrocidades em forma de manuais. É o caso de Heinrich Kramer e James Sprenger, monges dominicanos nomeados inquisidores, que escreveram o Malleus Maleficarum (tradução brasileira sob o título $O$ Martelo das Feiticeiras), ${ }^{11}$ publicado em 1487, considerado um manual indispensável para os operadores da Inquisição, e que devia ser seguido por todos os julgadores na luta contra a bruxaria na Europa Continental. Contudo, ele praticamente reproduz as práticas apresentadas por Eymerich.

9 Ibidem.

10 Cf. EYMERICH, Nicolau; PEÑA, Francisco. Manual dos Inquisidores. Rio de Janeiro: Rosa dos Tempos, 1993.

11 Cf. KRAMER, Heinrich; SPRENGER, James. 0 martelo das feiticeiras: malleus maleficarum. 12. ed. Rio de Janeiro: Rosa dos Tempos, 1997. 
Alguns pontos importantes descritos, implícita ou explicitamente nos manuais suprarreferidos e que serviram de norte para o sistema inquisitorial como um todo, merecem especial atenção e, portanto, serão tratados com destaque. 0 primeiro deles é o seu objeto de persecução. Durante o período em que o poder religioso confundia-se com o poder político, a Igreja Católica perseguia, torturava e matava vários de seus inimigos, ou quem ela entendesse como inimigo ou ameaça a seu poderio, sob a acusação do cometimento do crime de heresia, a fim de reprimir todo tipo de comportamento contrário aos ensinamentos cristãos. Num mundo teocrático, a transgressão da fé era também transgressão política.

Eymerich $^{12}$ aponta uma lista de sujeitos que eram considerados inimigos e que deveriam ser objeto de perseguição. Dentre eles estão os heresiarcas, blasfemadores, videntes, adivinhos, excomungados, cismáticos, apóstatas, aqueles que seguiam, hospedavam, protegiam ou se beneficiavam dos hereges, cristãos que aderissem ao judaísmo ou ao islamismo, todos os infiéis e quem se opusesse à fé cristã ou contestassem a autoridade da Igreja Católica, além daqueles que, direta ou indiretamente, se opusessem ao exercício ou que proferissem ameaças à Inquisição também seriam considerados e julgados como hereges.

Diante desse extenso rol, sob a análise de Carvalho, ${ }^{13}$ o sujeito a ser perseguido não era aquele que havia praticado uma conduta ilícita, mas sim aquele que apresentava personalidade considerada como perversa, perigosa ou herética. 0 infrator não era punido pelo dano que havia causado, mas sim pela sua periculosidade, perversidade e pela ameaça que representava para o sistema como um todo. No mesmo sentido, Khaled Jr. ${ }^{14}$ lembra

12 EYMERICH, Nicolau; PEÑA, Francisco. Op.cit. 1993, p. 36-75.

13 CARVALHO, Salo de. Pena e Garantias. 3. ed. ver. atual. Rio de Janeiro: Lumen Juris, 2008, p. 14-16.

14 KHALED JR., Salah H. Op.cit. 2016, p. 63. 
que a Inquisição não tinha relação direta com a criminalidade, mas sim com o desvio aos dogmas estabelecidos pela Igreja que pudessem ser ameaçados por novas crenças.

No intuito de combater tais inimigos, Eymerich ${ }^{15}$ refere que cabia a todos que soubessem, ou que já tivessem ouvido falar, que determinada pessoa era herege ou suspeita de heresia, a obrigação de delatá-las, sob pena de ser excomungado. Nas palavras de Leonardo Boff, no prefácio que faz à tradução brasileira do Manual dos Inquisidores, "os delatores são animados a delatar, pois a delação os faz obedientes à fé divina", ${ }^{16}$ e, portanto, não deveriam ser criticados, mas sim preservados.

Segundo os manuais inquisitoriais, o processo poderia ser iniciado a partir de três formas: acusação ou denúncia, feita por qualquer pessoa (delatores), ou, ainda, por investigação do próprio inquisidor. Os delatores eram ouvidos na justiça e eram obrigados a dizer a verdade. $\mathrm{Na}$ acusação, o delator sofreria as consequências da Lei de Talião caso restasse "perdedor". Contudo, Peña ${ }^{17}$ acrescentou que, se a Lei de Talião fosse aplicada, não se encontrariam mais delatores e, consequentemente, os crimes permaneceriam impunes, para grande prejuízo do Estado. Assim, o delator poderia limitar-se a fazer a denúncia para não correr o risco de ser excomungado (que acontecia àqueles que sabiam da existência de um crime de heresia, mas não delatavam). Caso o delator prestasse falso testemunho, seria condenado à prisão perpétua e o réu então seria libertado.

Havia ainda a preocupação em manter os delatores sob sigilo. Eymerich refere que seus nomes deveriam ser preservados em razão do perigo que poderia incorrer com a sua publicação e somente seriam divulgados se isso não causasse grandes riscos a eles:

15 EYMERICH, Nicolau; PEÑA, Francisco. Op.cit. 1993, p. 99.

16 BOFF, Leonardo. Prefácio. Inquisição: Um espírito que continua a existir. In: EYMERICH, Nicolau; PEÑA, Francisco. Manual dos Inquisidores. Rio de Janeiro: Rosa dos Tempos, 1993, p. 17.

17 EYMERICH, Nicolau; PEÑA, Francisco. Op.cit. 1993, p. 106. 
É bem mais perigoso divulgar nomes dos delatores de um pobre-diabo (alicui pauperi), cujos cúmplices e amigos não passam de rebeldes e homicidas, que só tem a pele a perder, do que divulgar os nomes dos delatores de uma pessoa generosa ou rica. ${ }^{18}$

Posteriormente, Peña destacou que tal divulgação não era mais possível, pois colocaria os delatores e seus familiares sob risco de morte ou de sérios atos de maldade. Assim, o réu jamais poderia saber quem o acusou, evitando represálias por parte de quem pudesse apoiá-lo. Além disso, tal preservação era de fundamental importância na medida em que, sem isso, seria malvisto quem testemunhasse contra os hereges ou denunciasse-os. Pela mesma razão, o delator deveria jurar guardar segredo sobre tudo que contou ao inquisidor.

A confissão é mais um aspecto a ser enfatizado, já que era indispensável no sistema inquisitório, não havendo qualquer limitação quanto aos meios utilizados para sua obtenção. Para Eymerich, ${ }^{19}$ ela era o meio mais rápido de se chegar à verdade, por isso o inquisidor deveria dizer ao acusado durante seu interrogatório que seria misericordioso com ele caso confessasse com clareza e rapidez. De acordo com as respostas do réu diante de questões previamente propostas pelo manual, o inquisidor deveria orientar suas próprias perguntas, cercando cada vez mais a questão fundamental da acusação, até chegar à "verdade", considerando sempre o acusado como culpado.

Eymerich $^{20}$ recomenda ainda que o inquisidor deveria ser muito malicioso e sagaz para acompanhar os hereges em seus argumentos a fim de levá-los a confessar (Francisco Peña, quando da revisão do manual, sugeriu acrescentar à malícia mais malícia ainda). Essa era "uma estratégia concebida para confundir o réu

18 EYMERICH, Nicolau; PEÑA, Francisco. Op.cit. 1993, p. 223.

19 Idem, p. 113-114.

20 Idem, p. 118. 
e dificultar sua resistência diante das artimanhas argumentativas de quem interroga". 21

Uma vez obtida a confissão não eram necessárias mais provas, pois a confissão do acusado tinha poder absoluto e era considerada a rainha das provas, sendo inútil qualquer outro meio de defesa ${ }^{22}$. Nesse sentido, como bem assinala Carvalho, ${ }^{23}$ a confissão era a prova suprema, considerada um meio altamente eficaz na busca da verdade. Conforme apontamentos de Francisco Peña no Manual dos Inquisidores, no caso de um homicídio, bastavam a confissão do criminoso e o cadáver da vítima para condená-lo; contudo, "o crime de heresia é concebido no cérebro e fica escondido na alma, portanto, é evidente que nada prova mais do que a confissão do réu". ${ }^{24}$ Tudo deveria ser feito para que o réu não pudesse se declarar inocente ou se desculpar, para não dar ao público o menor motivo para acreditar que a condenação era injusta.

A tortura também estava claramente descrita no Manual dos Inquisidores ${ }^{25}$ como uma forma de arrancar a confissão do acusado. Se o mesmo insistisse na negação da autoria do fato, e o inquisidor achasse que ele estava omitindo seus erros, apesar da evidência dos fatos e de depoimentos idôneos, o inquisidor deveria pressionar o sujeito a dizer a "verdade" e explicar-lhe que se não confessasse seria submetido à tortura.

O interrogatório do imputado era precedido ou seguido de torturas, que só cessavam quando o acusado expressasse sua vontade de confessar, e somente seria válida se confirmada no dia seguinte, quando em liberdade e não sob tortura. ${ }^{26}$ Lopes $\mathrm{Jr}^{27}$

21 KHALED JR., Salah H. Op.cit. 2016, p. 73-74.

22 MARCÃO, Renato. Curso de processo penal. 4.ed. São Paulo: Saraiva Educação, 2018, p. 87.

23 CARVAlHo, Salo de. Pena e Garantias. 3. ed. ver. atual. Rio de Janeiro: Lumen Juris, 2008, p. 20.

24 EYMERICH, Nicolau; PEÑA, Francisco. Op.cit. 1993, p. 138.

25 Idem, p. 208-213.

26 idem, p. 155.

27 LOPES JR, Aury; Op.cit. 2015, p. 148. 
destaca que a prisão do acusado era uma regra dentro do modelo inquisitorial para que o inquisidor o tivesse à sua disposição para torturá-lo conduzindo-o à confissão.

\begin{abstract}
Existiam cinco tipos progressivos de tortura, e o suspeito tinha o "direito" a que somente se praticasse um tipo por dia. Se em 15 dias o acusado não confessasse, era considerado "suficientemente" torturado e era liberado. Sem embargo, os métodos utilizados eram eficazes e quiçá alguns poucos tenham conseguido resistir aos 15 dias. 0 pior é que em alguns casos a pena era de menor gravidade que as torturas sofridas. ${ }^{28}$
\end{abstract}

Nesse sentido, Kramer e Sprenger ${ }^{29}$ ressaltam que era conveniente ao juiz manter a acusada na prisão por algum tempo ou anos, com o intuito de obter sua confissão, após sofrer os infortúnios do cárcere.

Cumpre destacar que a utilização da tortura no sistema inquisitório era empregada para ratificar hipóteses previamente acordadas sobre os fatos, ou seja, o inquisidor formulava uma premissa, não necessariamente baseada nos fatos em si, para direcionar seus questionamentos em busca da afirmação de sua suposição. Esses mecanismos estavam disciplinados nos manuais e regras impostas pelo Direito Canônico, justificando, assim, a utilização da tortura, que se mostrava cômoda e eficiente na busca da "descoberta da verdade". ${ }^{30}$

Ressalta-se, ainda, um último ponto que merece atenção dentro do sistema inquisitorial. Segundo Khaled Jr., ${ }^{31}$ a concepção de defesa de Eymerich revela que o sistema inquisitorial adequava-se perfeitamente aos regimes ditatoriais, totalitários e

\footnotetext{
28 Idem, p. 149.

29 KRAMER, Heinrich; SPRENGER, James. Op.cit. 1997, p. 413.

30 CARVALHO, Salo de. Op.cit. 2008, p. 21.

31 KHALED JR., Salah H. Op.cit. 2016, p. 73.
} 
antidemocráticos, uma vez que o direito de defesa do réu ensejava morosidade na tramitação do processo e atraso na prolação da sentença. Ideia corroborada por Francisco Peña, que considerava totalmente inútil a defesa. 0 inquisidor apenas atribuiria um advogado ao acusado, caso o mesmo continuasse negando a autoria dos fatos depois de três tentativas de obtenção da confissão. Para Peña, ${ }^{32}$ o papel do advogado era o de fazer com que o réu confessasse logo e demonstrasse arrependimento para que a pena fosse imediatamente aplicada e iniciada a execução. A defesa não trata de defender o réu, mas sim de agilizar a sua condenação.

No mesmo sentido, Kramer e Sprenger ressaltam que o juiz deve "dar prosseguimento ao julgamento da forma mais sumária possível, desautorizando [...] quaisquer contenções impertinentes de defensores ou advogados". ${ }^{33}$ Pacheco sintetiza a razão da dispensabilidade da figura do defensor no modelo inquisitorial: "se o réu era culpado, não o merecia; se era inocente, um juiz inquisidor honesto o descobriria". ${ }^{34}$

Diante de todos os aspectos até aqui analisados, resta clara a influência do Estado de Direito de forma direta e imediata no processo penal, questão incontestável para Lopes Jr. ${ }^{35}$ Tal premissa é visível na medida em que a valorização do homem e dos movimentos filosóficos, que surgiram durante a Revolução Francesa, repercutiu no processo penal, reduzindo gradativamente as características do sistema inquisitorial, predominante até finais do século XVIII, início do século XIX.

Nesse sentido, Khaled Jr. ${ }^{36}$ aponta a importância de pensadores iluministas para o início das reformas do modelo inquisitorial, destacando Montesquieu, com o desenvolvimento da legalidade e

32 EYMERICH, Nicolau; PEÑA, Francisco. Op.cit. 1993, p. 138-9.

33 KRAMER, Heinrich; SPRENGER, James. Op.cit. 1997, p. 406.

34 PACHECO, Denilson Feitoza. Direito processual penal: teoria, crítica e práxis. 5. ed. rev. atual. Niterói, RJ: Impetus, 2008, p. 55.

35 LOPES JR, Aury; Op.cit. 2015, p. 150. 
da separação dos poderes e que defendeu também a ideia de que a liberdade dos cidadãos dependia da excelência das leis criminais e que se a inocência não está garantida, a liberdade também não está, além de Locke e Voltaire, que introduziram paulatinamente ideias de tolerância, posteriormente transpostas para o direito penal através de Beccaria, Verri e Bentham.

Tais ideias foram ganhando espaço na sociedade. Ademais, as duras críticas feitas aos abusos no Tribunal da Inquisição também começaram a se difundir. Dentre elas, o repúdio à barbárie das práticas utilizadas, a ponto de se torturar tanto o acusado que ele era obrigado a se declarar culpado, trouxe à consciência, por exemplo, a noção de que a tortura era uma forma injusta de provar delitos, e que acabava sendo utilizada apenas como um meio de revelação de cúmplices.

É imprescindível ressaltar a importante contribuição de Beccaria $^{37}$ na supressão de várias medidas utilizadas no sistema inquisitorial. Em sua obra "Dos delitos e das penas", ele defendeu a publicidade do julgamento, a proporcionalidade entre os delitos e as penas, criticou as acusações secretas, a brutalidade das penas, as condenações de crimes sem provas, os interrogatórios sugestivos e o emprego da tortura.

Com o estabelecimento do Estado Moderno, e a consequente "laicização do Estado e do direito, o crime não corresponde mais à violação do divino, mas à livre e consciente transgressão da norma jurídica promulgada pelo Estado",38 ficando o infrator submetido à penalidade correspondente previamente conhecida.

Em que pese a maioria das medidas adotadas na época da Inquisição não estejam mais presentes no sistema processual penal atual, para Boff é possível encontrar seus resquícios no atual Direito Canônico, como, por exemplo, no processo de delação,

37 Cf. BECCARIA, Cesare. Dos delitos e das penas. São Paulo: Martin Fontes, 1997. (Coleção Clássicos).

38 CARVALHO, Salo de. Op.cit. 2008, p. 41. 
ou quando é negado o acesso aos autos do processo, quando há impossibilidade de apelação, ou mesmo na medida em que, por vezes, é a mesma instância que acusa, julga e pune, não havendo preservação do direito de defesa, ao que o autor considera uma "perversidade jurídica em qualquer Estado de direito, pagão, ateu ou cristão". ${ }^{39}$ Tal análise também é cabível no nosso Código de Processo Penal, instituído em 1941, logo após a instauração do autoritário Estado Novo em 1937, que, apesar das inúmeras alterações posteriores, sofreu influências da legislação italiana da década de 1930, com raízes no sistema inquisitório e que estava sob um regime fascista. Khaled Jr. também ressalta que várias premissas contidas no texto de Eymerich, "até hoje conformam uma movimentação nitidamente persecutória da máquina processual, fazendo com que sua estrutura seja voltada para a busca da verdade, ou seja, para a condenação". ${ }^{40}$

\section{A COLABORAÇÃO PREMIADA NO PROCESSO PENAL BRASILEIRO}

Os princípios de política processual de uma nação são um segmento de sua política estatal geral, expressos, em regra, na constituição de cada Estado, como bem ensina Marques. ${ }^{41}$ Assim, a uma nação que adota uma constituição democrática, como é o caso da Constituição da República Federativa do Brasil de 1988, deve corresponder um processo penal democrático. Apesar de algumas críticas e entendimentos doutrinários no sentido de que o modelo brasileiro seguiria um sistema misto, já que possui uma fase pré-processual de cunho aparentemente inquisitório, o sistema processual penal adotado pela Constituição de 1988 é o acusatório, na medida em que inclui em seu texto diversos princí-

39 BOFF, Leonardo. Prefácio. In: EYMERICH, Nicolau; PEÑA, Francisco. Op.cit. 1993, p. 25.

40 KHALED JR., Salah H. Op.cit. 2016, p. 65.

41 MARQUES, José Frederico. Elementos de direito processual penal. v. 1. 2. ed. Campinas: Millennium, 2000, p.77. 
pios e garantias ao acusado, inexistente no sistema inquisitorial, e definiu as funções de acusar e julgar em órgãos distintos (Ministério Público e Poder Judiciário, respectivamente), cuja separação seria o critério definidor de um sistema ou outro, e que somente se verifica no modelo acusatório, conforme pondera Lopes Jr.. ${ }^{42}$

Em um Estado Democrático de Direito, é ele próprio o único detentor do jus puniendi, sendo essa uma das características de sua soberania. Frente às dificuldades do Estado em punir crimes praticados em concurso de agentes, geralmente em razão de sua complexidade e sofisticação, a colaboração dos acusados no curso do processo penal vem se mostrando de extrema importância ao longo do tempo. No Brasil, como bem lembra Salomi ${ }^{43}$ desde as Ordenações Filipinas do século XVII, com a previsão dos crimes de falsificação de moeda e de "Lesa Majestade" na época em que ainda era colônia de Portugal, que vigorou até o advento do Código Criminal de 1830, a delação já era tratada com certa relevância para o processo penal, uma vez que benesses eram ofertadas àqueles que delatassem seus comparsas, podendo alcançar, inclusive, o perdão judicial. Desde então, tal forma de cooperação vem se desenvolvendo e ganhando força no decorrer do tempo.

A delação premiada como forma de colaboração processual penal na nova era democrática do Brasil teve como marco inicial a Lei de Crimes Hediondos (Lei 8.072/1990), que surgiu como uma resposta ao apelo da sociedade (provocado em grande parte por um sensacionalismo midiático) frente ao aumento da criminalidade violenta em larga escala, e que consistia em um benefício penal, concedido diretamente pelo juiz, ao indiciado que colaborasse com as autoridades. ${ }^{44}$

42 LOPES JR, Aury. Op.cit. 2008, p. 67.

43 SALOMI, Maíra Beauchamp. Colaboração premiada: principais questões acerca da competência para homologação. In: BOTTINI, Pierpaolo Cruz; MOURA, Maria Thereza de Assis (coordenação). Colaboração Premiada. São Paulo: Revista dos Tribunais, 2017, p.153.

44 COSTA, Leonardo Dantas. Delação premiada: a atuação do Estado e a relevância da voluntariedade do colaborador com a justiça. Curitiba: Juruá, 2017. p. 84-5. 
A partir de então, outros dispositivos legais foram sendo inseridos no ordenamento jurídico brasileiro, de forma esparsa, a fim de positivar formas de o acusado colaborar com as investigações e com o processo como um todo, com a contrapartida de obtenção de benesses em eventual condenação. Dentre eles é possível citar a antiga Lei de Combate ao Crime Organizado (Lei 9.034/1995), a Lei 9.080/1995, que introduziu formas de colaboração do indiciado na Lei dos Crimes Contra o Sistema Financeiro (Lei 7.492/1986) e na Lei dos Crimes Contra a Ordem Tributária, Econômica e Outras Relações de Consumo (Lei 8.137/1990), a Lei 9.269/1996 que alterou dispositivo no próprio Código Penal e a Lei de Lavagem de Dinheiro (Lei 9.613/1998), todas com previsão de redução de pena para o acusado colaborador.

Segundo Costa, ${ }^{45}$ a Lei de Proteção às Vítimas e Testemunhas (Lei 9.807/1999) foi de extrema importância para o desenvolvimento do instituto da delação premiada no país, uma vez que passou a ser aplicada a qualquer tipo penal, inseriu a possibilidade de extinção da punibilidade pelo perdão judicial, além de criar um sistema de proteção aos colaboradores e familiares, já que havia um desestímulo à colaboração em razão do medo de represália por aqueles que eram incriminados pelos delatores.

Contudo, diante da inexistência de um procedimento legal para a realização dos acordos de colaboração premiada, a prática forense encontrou dificuldades para sua aplicação, comprometendo as próprias garantias processuais e a efetivação da garantia da voluntariedade da colaboração. Nesse contexto, a Lei 12.850/2013 (Lei de Combate às Organizações Criminosas) supriu, ainda que parcialmente, essa lacuna legislativa, introduzindo no ordenamento jurídico brasileiro o instituto da colaboração premiada com o respectivo procedimento para sua implementação. ${ }^{46}$

45 COSTA, Leonardo Dantas. Delação premiada: a atuação do Estado e a relevância da voluntariedade do colaborador com a justiça. Curitiba: Juruá, 2017. p. 89-92.

46 Idem. p. 99-101. 
Cabe ressaltar que a lei supracitada regulou o instituto conferindo-lhe o termo colaboração premiada, diferenciando-o, portanto, de delação premiada. 0 abandono do termo delação pelo legislador gerou várias discussões doutrinárias. Embora por diversas vezes tais denominações sejam utilizadas como sinônimos, elas possuem diferenças importantes.

A doutrina pátria costuma classificar a delação premiada como sendo de natureza material, uma vez que o juiz concede um benefício (geralmente relativo à redução da pena) ao acusado quando preenchidas as condições legais para tal. Costa assim conceitua o instituto:

A delação premiada é um instituto de iniciativa exclusiva do juiz que, verificando a colaboração efetiva e voluntária (ou, se for o caso, espontânea) do acusado, concede-lhe benefício que se reflete no cumprimento de sua pena. Não prescinde de participação do Ministério Público, posto que não é, propriamente, um acordo entre as partes do processo penal. Assim, perfaz-se como um instituto de direito material, consistente na concessão de benefício pela autoridade judicial, mediante o preenchimento dos requisitos legais para tanto. ${ }^{47}$

Já a colaboração premiada, disciplinada pela Lei 12.850/2013, é considerada como um meio de obtenção de prova, conforme prevê o inciso I do artigo $3^{\circ}$ da referida lei (inserida no Capítulo II - Da Investigação e dos Meios de Obtenção de Prova), permitida em qualquer fase da persecução penal, inclusive em sede de execução da pena, e não conta com a participação do juiz (esse cumpre apenas a função fiscalizatória da legalidade, regularidade e voluntariedade do acordo). Assim, a Lei de Combate às Organizações Criminosas consolidou a colaboração premiada como sendo de natureza processual, uma vez que o principal ob-

47 Idem, p. 82. 
jetivo do instituto é facilitar a persecução penal através da confissão e cooperação do delator, que poderá proporcionar celeridade na produção e obtenção de elementos probatórios, tais como a indicação de corréus e apresentação de provas documentais. ${ }^{48}$ No mesmo sentido, Rosa assim dispõe:

A ausência de delatores torna a tarefa investigativa complexa, demorada e cara. 0 atalho proporcionado é valioso e deve ser considerado no contexto de organizações criminosas autênticas, já que as limitações estatais são preenchidas pela colaboração interessada de insiders. ${ }^{49}$

Impende destacar que o acordo de colaboração premiada não pode ser confundido com os depoimentos prestados pelo próprio colaborador. O Supremo Tribunal Federal, no julgamento do HC 127.483/PR reforçou tal entendimento:

Enquanto que o acordo de colaboração é meio de obtenção de prova, os depoimentos propriamente ditos do colaborador constituem meio de prova, que somente se mostrarão hábeis à formação do convencimento judicial se vierem a ser corroborados por outros meios idôneos de prova. ${ }^{50}$

O mesmo julgado ressalta que o acordo de colaboração previsto na Lei 12.850/2013 é um negócio jurídico processual, na medida em que presentes os requisitos dos planos da existência, da validade e da eficácia. A doutrina majoritária segue no mesmo sentido, já que, como bem lembra Mendonça, o acordo

48 VASCONCELLOS, Vinicius Gomes de. Op.cit. 2017, p. 55.

49 ROSA, Alexandre Morais da. Para entender a delação premiada pela teoria dos jogos: táticas e estratégias no negócio jurídico. Florianópolis: EModara, 2018, p. 15.

50 STF. Habeas Corpus. HC 127.483/PR. Relator: Ministro Dias Toffolli, Tribunal Pleno, julgado em 27.08.2015, p. 21. 
é "bilateral, pois gera direitos, faculdades, ônus, obrigações e deveres recíprocos". ${ }^{51}$

Para Bottino, ${ }^{52}$ uma das grandes diferenças entre os institutos recai sobre a (in)certeza do(s) benefício(s) que será(ão) recebido(s) pelo delator/colaborador, trazendo maior segurança para as partes quando se trata da colaboração prevista na Lei 12.850/2013, vinculando não somente os limites do acordo, como o próprio órgão jurisdicional, na medida em que esse homologa o acordo firmado entre as partes.

Os artigos $4^{\circ}$ a $7^{\circ}$ da lei supracitada são os que regulamentam o processo do acordo de colaboração. Em linhas gerais, o instituto da colaboração premiada inclui negociação, formalização, homologação, execução e concessão do benefício e, por isso, é considerado um fenômeno complexo, que compreende diversos atos (majoritariamente processuais), e não apenas o depoimento do acusado. Bem mais amplo, portanto, do que a delação premiada, que parte da exclusiva inciativa do juiz, com reflexos somente na pena e, portanto, restrita a um instituto de direito material.

Como bem ressalta Costa, a colaboração premiada "pressupõe cooperação entre as partes do processo penal, institui obrigações recíprocas e confere direitos". ${ }^{33}$ Para a finalidade que se propõe o presente artigo, será feita, inicialmente, uma análise do instituto através dos dispositivos da Lei 12.850/2013 sob alguns aspectos específicos: partes legitimadas, benefícios passíveis de acordo, efetividade da colaboração, necessidade de defensor, importância da voluntariedade e do acesso às informações ao colaborador, homologação judicial e renúncia ao direito ao silêncio.

51 MENDONÇA, Andrey Borges de. Os benefícios possíveis na colaboração premiada: entre a legalidade e a autonomia da vontade. In: BOTTINI, Pierpaolo Cruz; MOURA, Maria Thereza de Assis (coordenação). Colaboração Premiada. São Paulo: Revista dos Tribunais, 2017, p. 54.

52 BOTTINO, Thiago. Colaboração premiada e incentivos à cooperação no processo penal: uma análise crítica dos acordos firmados na "Operação Lava Jato". Revista Brasileira de Ciências Criminais, São Paulo, v. 24, n. 122, ago. 2016, p. 7.

53 COSTA, Leonardo Dantas. Op.cit. 2017, p. 106. 
Conforme o artigo $4^{\circ}$, $\S^{\circ}$ do referido diploma legal, a colaboração premiada é um acordo realizado "entre o delegado de polícia, o investigado e o defensor, com a manifestação do Ministério Público, ou, conforme o caso, entre o Ministério Público e o investigado ou acusado e seu defensor", portanto, sem a participação do juiz. Assim, as partes legitimadas para propor o acordo são a autoridade policial (durante a fase preliminar de investigação, ainda que criticada sua legitimidade por alguns doutrinadores) ou o Ministério Público, titular da ação penal pública, a qualquer tempo, de acordo com a sua discricionariedade. Cabe ressaltar que "todos os atos de negociação praticados pela autoridade policial devem, necessariamente, ser apreciados pelo Ministério Público". ${ }^{54}$

Percebe-se da simples leitura do artigo supracitado que o ente ministerial assume uma elevada importância no procedimento da colaboração premiada na medida em que se tornou obrigatória a sua atuação na formulação do acordo, sendo como parte ou manifestando a sua posição quando o acordo for celebrado entre o acusado e a autoridade policial. Contudo, a intervenção do Ministério Público resta um tanto que restrita às possibilidades de negociação permitidas pelo artigo $4^{\circ} \mathrm{o}$ da Lei 12.850/2013. Como bem aponta Vasconcellos, "o regime da colaboração premiada deve, necessariamente, ser limitado, com o máximo respeito à legalidade". 55

Os benefícios previstos na lei que o ente ministerial (ou o delegado de polícia) pode propor ao colaborador, que eventualmente serão concedidos pelo juiz quando da prolação da sentença, são: concessão do perdão judicial, redução em até 2/3 (dois terços) da pena privativa de liberdade ou substituição da mesma por uma pena restritiva de direitos. Caso o acordo seja firmado após a sentença condenatória, os benefícios que poderão

54 COSTA, Leonardo Dantas. Op.cit. 2017, p. 117.

55 VASCONCELLOS, Vinicius Gomes de. Op.cit. 2017, p. 149. 
ser propostos restringem-se a redução da pena até a metade ou a admissão da progressão de regime, mesmo quando ausentes os requisitos para tal. Há ainda a possibilidade de o Ministério Público deixar de oferecer a denúncia se o colaborador não for o líder da organização criminosa ou se for o primeiro a prestar efetiva colaboração, nos termos previstos no artigo 40 e seus parágrafos da Lei 12.850/2013.

Ademais, para que o acordo de colaboração possa ser firmado entre as partes é imprescindível que o acusado (ou investigado), além de confessar sua participação no crime a que lhe é imputado, forneça informações acerca da organização criminosa. Todavia, a colaboração deverá também ser efetiva, ou seja, deverá alcançar algum dos resultados previstos nos incisos do mesmo dispositivo legal, quais sejam:

I - a identificação dos demais coautores e partícipes da organização criminosa e das infrações penais por eles praticadas;

II - a revelação da estrutura hierárquica e da divisão de tarefas da organização criminosa;III - a prevenção de infrações penais decorrentes das atividades da organização criminosa;

IV - a recuperação total ou parcial do produto ou do proveito das infrações penais praticadas pela organização criminosa;

V - a localização de eventual vítima com a sua integridade física preservada.

Conforme assinala Costa, ${ }^{56}$ os objetivos elencados nos incisos supracitados são alternativos, passíveis de negociação de acordo com as informações que o colaborador possui e com a necessidade de investigação dos órgãos estatais, na medida em que se torna um potencial facilitador da persecução penal.

56 COSTA, Leonardo Dantas. Op.cit. 2017, p. 136. 
Porém, Vasconcellos ${ }^{57}$ ressalta que, em que pese os resultados esperados da colaboração devam estar especificados de modo objetivo e delimitado no termo do acordo, o delator não pode descrever profundamente todos os fatos incriminatórios que tem conhecimento, sob pena de inviabilizar a realização do acordo.

É imperioso destacar a imposição da assistência por defensor em todos os atos de negociação, confirmação e execução da colaboração, prevista no artigo $4^{\circ}$, $\$ 15$ e no artigo 6ํㅡ, III, da Lei 12.850/2013. Rosa ${ }^{58}$ evidencia que a inobservância de tal dispositivo pode acarretar a nulidade dos atos subsequentes da negociação, sendo vedado, portanto, o início das tratativas de um possível acordo de colaboração premiada sem a presença de defesa técnica. Tal garantia também se faz necessária "como medida para proteger a voluntariedade e a inteligência/informação do consentimento do imputado". ${ }^{59}$

Outro ponto que merece especial atenção para que haja uma colaboração eficaz é a voluntariedade do agente, expressa no caput e no $\$ 7^{\circ}$ do artigo $4^{\circ}$ da Lei $12.850 / 2013$, requisito que também deve ser observado pelo juiz quando da homologação do acordo. 0 que não se confunde com a espontaneidade, ou seja, a voluntariedade não implica em dizer que a ideia de colaborar deve partir do próprio agente. Como já abordado anteriormente, o acordo pode ser proposto pela autoridade policial ou pelo Ministério Público. Contudo, o acusado não pode ser obrigado a colaborar: daí advém a voluntariedade. Como bem aponta Costa, “o cerne da voluntariedade é a ausência de pressões ou coações, sejam físicas ou psicológicas, que retirem a liberdade de escolha sobre a prática do ato". ${ }^{60}$

57 VASCONCELLOS, Vinicius Gomes de. Op.cit. 2017, p. 168.

58 ROSA, Alexandre Morais da. Op.cit. 2018, p. 149.

59 VASCONCELLOS, Vinicius Gomes de. Op.cit. 2017, p. 146.

60 COSTA, Leonardo Dantas. Op.cit. 2017, p. 171. 
No mesmo sentido, Mendonça ressalta a importância da voluntariedade do colaborador já que é a essência do negócio celebrado, inclusive como estratégia de defesa. Acrescenta ainda:

0 imputado jamais pode ser obrigado a firmar um acordo de colaboração, que sempre deve ser voluntário. Qualquer forma de constrição - como o uso da prisão preventiva ou qualquer outra forma de coação, física ou moral - para constranger alguém a realizar um acordo de colaboração é ilícita. ${ }^{61}$

Além disso, para que o colaborador possa formar sua livre convicção na tomada da decisão em cooperar com a Justiça, e para que ela seja o mais franca possível, é necessário que o mesmo tenha acesso a todas as informações acerca das circunstâncias em que está sendo negociado o acordo, bem como qual o conteúdo das investigações feitas até o momento, "sob pena de pautar sua vontade em falsas premissas ou em premissas incompletas". ${ }^{62}$ Ainda, o colaborador deve conhecer as acusações a ele imputadas, compreender as consequências do acordo, bem como ter ciência de todos os direitos e as renúncias que estará realizando. Desse modo, o direito à informação é requisito imprescindível para garantir a voluntariedade do ato, bem como para que seja exercida a ampla defesa da forma em que é garantida constitucionalmente.

Feitas as negociações, ou seja, definidas claramente as propostas de benefícios, as metas a serem atingidas e as obrigações das partes, o acordo deve ser formalizado devendo preencher os seguintes requisitos previstos nos incisos do artigo $6^{\circ}$ da Lei 12.850/2013:

I - o relato da colaboração e seus possíveis resultados;

II - as condições da proposta do Ministério Público ou do delegado de polícia;

61 MENDONÇA, Andrey Borges de. Op.cit. 2017, p. 60.

62 COSTA, Leonardo Dantas. Op.cit. 2017, p. 129. 
III - a declaração de aceitação do colaborador e de seu defensor;

IV - as assinaturas do representante do Ministério Público ou do delegado de polícia, do colaborador e de seu defensor;

V - a especificação das medidas de proteção ao colaborador e à sua família, quando necessário.

Ademais, o termo do acordo "deve ser claro de maneira a evidenciar a legalidade, regularidade e voluntariedade do acordo, requisitos formais para que o juízo proceda a sua homologação". ${ }^{63}$

Uma vez celebrado o acordo, ele será submetido ao crivo do juiz competente para homologação, que deverá fazer um controle dos aspectos formais e demais elementos do termo e da negociação quando de sua formalização. No momento da análise da voluntariedade, referida anteriormente, além da verificação se houve pressões ou coações indevidas por parte da autoridade estatal, o juiz deve observar a regularidade (participação do defensor, forma escrita, disposição das cláusulas, etc.) e a legalidade do acordo, que engloba não somente a conformidade com a lei, mas se está em consonância com os princípios da proporcionalidade e razoabilidade de sua aplicação, além de verificar a existência de eventuais abusos nas cláusulas pactuadas ou contrárias ao direito, sem que faça juízo de valor acerca da eficácia da colaboração nesse momento, que somente poderá ser feito quando da prolação da sentença. ${ }^{64}$ Caso entenda necessário, o juiz poderá ouvir sigilosamente o colaborador, na presença de seu defensor, a fim de garantir a presença de tais elementos, especialmente o da voluntariedade.

Vasconcellos ${ }^{65}$ bem observa que a formalização e a homologação do acordo conferem mais segurança e previsibilidade à colaboração premiada, razão pela qual a efetiva cooperação só

63 COSTA, Leonardo Dantas. Op.cit. 2017, p. 147.

64 Idem, p. 148-149.

65 VASCONCELLOS, Vinicius Gomes de. Op.cit. 2017, p. 182. 
pode ocorrer após a judicialização do mesmo, de modo que é a única forma compatível de respeitar o direito à defesa e ao contraditório, fatores que condicionam a lícita formação das provas incriminatórias dos delatados. Por tal razão, é imprescindível que o juiz não faça parte das negociações, atuando apenas como um fiscalizador da celebração do acordo de colaboração quando de sua homologação, "restringindo seu papel ao de garantidor da legalidade e do respeito aos direitos fundamentais do acusado por meio do controle acerca da homologação do acordo". ${ }^{66}$

Em que pese a interferência do juiz no momento da homologação do acordo deva ser restrita aos quesitos supramencionados, sem que haja um aprofundamento acerca do caso, sua atuação nesse momento não pode ser muito superficial, já que o julgador fica de certo modo vinculado ao acordo quando do sentenciamento. Em última análise, o acordo é realizado pelo próprio Estado, seja no papel do delegado de polícia ou do representante do Ministério Público, quando formalizam o acordo, seja na figura do juiz, quando da homologação do acordo e que, portanto, resta a ele vinculado, como bem lembram Canotilho e Brandão:

Homologando o acordo, o juiz não se limita a declarar a sua validade legal, mas também, de certo modo, assume um compromisso em nome do Estado: ocorrendo a colaboração nos termos pactuados e sendo ela eficaz, em princípio devem ser outorgadas ao réu colaborador as vantagens que lhe foram prometidas. ${ }^{67}$

66 VASCONCELLOS, Vinicius Gomes de. Barganha e justiça criminal negocial: análise das tendências de expansão dos espaços de consenso no processo penal brasileiro. São Paulo: IBCCRIM, 2015, p. 122.

67 CANOTILHO, J. J. Gomes; BRANDÃO, Nuno. Colaboração Premiada: reflexões críticas sobre os acordos fundantes da Operação Lava Jato. Revista Brasileira de Ciências Criminais. vol. 133. ano 25. p. 133-171. São Paulo: Ed. RT, jul. 2017, p. 150. 
Outro aspecto de grande relevância que será aqui abordado acerca da colaboração premiada é a previsão, no artigo $4 \stackrel{0}{0}, \S 14$ da Lei 12.850/2013, da renúncia ao direito do silêncio ou, como preferem alguns doutrinadores, a renúncia ao direito de não autoincriminação, garantia fundamental prevista na Constituição Federal de 1988, no artigo 5º , inciso LXIII. A polêmica acerca do tema gera grandes divergências na doutrina.

Por um lado, há quem entenda que inexiste inconstitucionalidade e violação aos direitos do colaborador desde que o mesmo não seja compelido a colaborar (por isso a importância da voluntariedade) e que tenha ciência de que está renunciando ao direito de permanecer calado. Para Costa "a colaboração premiada pressupõe a confissão dos fatos que o colaborador tenha participado e a necessária renúncia ao silêncio". ${ }^{68}$ Por outro lado, há quem defenda, como Vasconcellos, ${ }^{69}$ que o imputado não é obrigado a se autoincriminar, na medida em que a própria Lei 12.850/2013 prevê a possibilidade de retratação do acordo, faculdade conferida às partes no artigo 4ํㅡ, $\$ 10$ do referido diploma legal.

Ressalte-se que não se pode confundir a renúncia ao direito ao silêncio previsto na Lei de Combate às Organizações Criminosas com o instituto da confissão disciplinada no artigo 65, inciso III, alínea 'd', do Código Penal que prevê a atenuação da pena para aqueles que confessarem a autoria do crime, e que independe de qualquer outra colaboração. Essa possui natureza de direito material, e implica diretamente na graduação da pena a ser aplicada no sentenciamento. Contudo, tal dispositivo legal prevê a espontaneidade da confissão, requisito que, conforme abordado previamente, pouco importa para a colaboração premiada.

Por fim, cabe ainda pontuar a previsão legal acerca do sigilo da colaboração, do colaborador e do objeto, como forma de garantir o êxito das investigações, sendo o acesso aos autos restrito

68 COSTA, Leonardo Dantas. Op.cit. 2017, p. 132.

69 VASCONCELLOS, Vinicius Gomes de. Op.cit. 2017, p. 166. 
às autoridades estatais e à defesa do representado, mediante autorização judicial, sendo somente retirado o sigilo quando recebida a denúncia, garantidos os direitos do colaborador. Para Vasconcellos (2017), o sigilo deveria ser a exceção, e não a regra, a fim de assegurar a defesa e o contraditório dos delatados:

Por óbvio, também existem hipóteses em que o sigilo é necessário e recomendável, desde que se comprove eventual risco ao colaborador ou à realização de atos investigativos específicos, como interceptações telefônicas, por exemplo. Assim, em situações de necessidade de sigilo, ao remeter o termo do acordo formalizado, o acusador deveria requerer a restrição à publicidade por prazo determinado. ${ }^{70}$

Diante do exposto, resta imprescindível uma análise mais aprofundada acerca de como a lei vem sendo aplicada nos acordos de colaboração premiada, sobretudo naqueles celebrados na Operação Lava Jato, traçando um possível paralelo com as práticas inquisitoriais analisadas no primeiro capítulo.

4 PROCESSO PENAL DEMOCRÁTICO EM RISCO? OS INFLUXOS INQUISITORIAIS NO INSTITUTO DA COLABORAÇÃO PREMIADA E EM SUA APLICAÇÃO NO BRASIL

Para além da Lei de Combate às Organizações Criminosas, os acordos de colaboração premiada que vêm sendo feitos nos últimos anos, notadamente no âmbito da Operação Lava Jato, devem ser analisados com cautela, uma vez que parecem resgatar algumas práticas utilizadas pelos Tribunais da Inquisição, não compatíveis com os princípios gerais do sistema processual penal democrático. Por óbvio que não se está aqui sustentando uma proteção aos crimes de corrupção e lavagem de dinheiro, que merecem total repúdio já que, ao fim, afetam todos os indivíduos

70 VASCONCELLOS, Vinicius Gomes de. Op.cit. 2017, p. 241. 
de uma nação. 0 que se pretende é apenas analisar o instituto sob uma perspectiva técnica processual. Ressalta-se que tampouco se espera esgotar uma possível equiparação das práticas inquisitoriais com a aplicação atual do instituto da colaboração premiada, mas apenas pontuar alguns aspectos mais relevantes que merecem especial atenção no mundo jurídico.

Como já referido, o sistema inquisitorial caracterizou-se pela perseguição desenfreada a quem a Igreja Católica considerava seus inimigos, na busca pela descoberta de crimes, não somente daqueles que já estavam sendo investigados, como também de outros ignorados pelo Estado, incentivando (e até obrigando) as pessoas a delatarem crimes de heresia que tivessem notícia. Do mesmo modo, diante do expressivo número de acordos celebrados na Operação Lava Jato somente no estado do Paraná (de agosto de 2014 até o dia 08 de novembro de 2018 foram 176 acordos de colaboração premiada firmados com pessoas físicas, em 82 acusações criminais contra 374 pessoas) ${ }^{71}$, questiona-se se não está havendo um incentivo por parte do Estado nesse tipo de negociação, uma espécie de banalização da utilização do instituto, na busca incessante pela descoberta de mais crimes, além daqueles já objeto de investigação.

Tal situação enseja uma verdadeira inversão da colheita de provas, muito em razão da ineficiência do próprio Estado que se torna dependente da colaboração do acusado, já que é ele quem terá que provar as alegações apontadas na celebração do acordo. Nesse sentido, Vasconcellos ${ }^{72}$ sugere que a justiça negocial criminal remonta a um modelo inquisitivo, uma vez que distorce as características acusatórias, na medida em que se imputa ao acusado a formação de provas, retirando do Estado tal incum-

71 BRASIL. Ministério Público Federal. A Lava Jato em números no Paraná. Disponível em: <http://www.mpf.mp.br/para-o-cidadao/caso-lava-jato/ atuacao-na-1a-instancia/atuacao-na-1a-instancia/parana/resultado $>$. Acesso em: 08 nov. 2018.

72 VASCONCELLOS, Vinicius Gomes de. Op.cit. 2017, p. 44. 
bência que lhe é própria. Parece evidente que, assim como nos Tribunais da Inquisição, há uma busca pela condenação, esvaziando o princípio da presunção da inocência, princípio basilar do sistema acusatório. ${ }^{73}$

Ademais, o então ministro do Superior Tribunal de Justiça (STJ) Néfi Cordeiro, ${ }^{74}$ em conferência realizada no Tribunal Regional Federal da 4⿳亠丷a Região sobre o tema "Controle Judicial da Colaboração Premiada" (informações orais), bem lembra que o instituto possui caráter extraordinário, devendo, portanto, ser utilizado como última providência, sob o risco de banalizar o instituto, transformando um processo que era para ser ordinário, em um processo penal do inimigo já que acaba por investigar não mais um fato, mas sim pessoas. Outrossim, o ministro lembra ainda que, em que pese a colaboração premiada seja positiva face a sua eficiência, trata-se de provas altamente invasivas de direitos individuais ou altamente transformadoras da lógica do jogo do processo, razão pela qual sua utilização deve ser feita com moderação.

Do mesmo modo que acontecia no processo inquisitório, o acordo de colaboração premiada corre em sigilo, sob a mesma argumentação de proteção das investigações, bem como do próprio delator/colaborador e para garantir a busca pela "verdade real". A necessidade do sigilo, além de parecer também mais uma busca pela condenação, como já referido, para alguns doutrinadores tal particularidade deveria ser a exceção, e não a regra, a fim de assegurar a defesa e o contraditório dos delatados, já que tais garantias constitucionais são características marcantes do sistema penal acusatório, e, portanto, do processo penal brasileiro, permitindo ao acusado sua ampla defesa.

73 Idem, p. 39.

74 Conferência destinada aos magistrados federais da 4 a região, servidores, convidados e estagiários da corte. CORDEIRO, Néfi. Controle Judicial de Colaboração Premiada. Porto Alegre, Tribunal Regional Federal da $4 \underline{a}$ Região, 24 set. 2018. 
A imensa valorização da confissão é outro ponto importante passível de equiparação entre o sistema inquisitorial e o instituto da colaboração premiada, também como uma espécie de busca pela verdade, uma vez que era o meio mais rápido de se chegar a ela. Essa hipervalorização da confissão, pelo sistema negocial criminal, remonta aos modelos penais autoritários que conduzem o processo visando tão somente à condenação do acusado, tratando o sujeito como objeto da investigação e não como sujeito de direitos, não havendo igualdade entre as partes. Assim, abre-se também a discussão acerca da renúncia ao direito ao silêncio, prevista expressamente no artigo 4oㅗ $§ 14$ da Lei 12.850/2013, assumindo, o colaborador, a obrigação legal de dizer a verdade.

0 ministro Néfi Cordeiro ${ }^{75}$ considera que a própria confissão, prevista no artigo 65, inciso III, alínea 'd', do Código Penal, é uma forma de colaboração do réu com o processo, já que abre mão do seu direito de ficar calado em troca de benefícios penais, o que enseja a renúncia ao direito ao silêncio, uma vez que é uma faculdade do acusado. Para ele, deve haver uma coerência sistêmica, ou seja, o mesmo entendimento deve ser aplicado a todos os institutos, inclusive à colaboração premiada. Por essa razão, o ministro entende que não há violação ao direito ao silêncio, previsto no artigo 5o, inciso LXIII da Constituição Federal de 1988, na medida em que o réu/colaborador aceita os termos da renúncia em um ato de opção individual, por isso repisa a importância da voluntariedade e a presença de defesa técnica na celebração do acordo. Especificamente sobre os acordos celebrados na Operação Lava Jato, o ministro ressalta que se trata de uma criminalidade sofisticada que dificulta a investigação por parte do Estado e que somente poderá ser desvelada com a colaboração dos envolvidos, não havendo lugar para a ingenuidade, uma vez que as partes estão devidamente representadas e sabem (ou deveriam saber) a exata medida que estão cedendo e o que querem em troca.

75 CORDEIRO, Néfi. Op.cit. 
No mesmo sentido, Bottino ${ }^{76}$ ressalta que o colaborador avalia o benefício e o custo esperado, sendo que a opção de colaborar é uma escolha consciente e voluntária. E, assim, conclui que "por se tratar de uma decisão informada e assistida pela defesa técnica, pode-se falar que estão presentes os requisitos para que a opção pela colaboração se caracterize como uma escolha racional". ${ }^{77}$ Por outro lado, Vasconcellos alerta que tal renúncia é utilizada como forma de pressionar o acusado a colaborar, ocasionando consequências trágicas à justiça criminal:

De qualquer modo, é inegável a tendência contemporânea de relativização e esvaziamento do direito a não autoincriminação, ao passo que cada vez mais o Estado desconsidera a carga probatória imposta à acusação e utiliza-se de pressões e "incentivos" para contar com a cooperação do próprio acusado para legitimar a própria punição. ${ }^{78}$

De qualquer sorte, a colaboração premiada é uma nova ferramenta compatível com a dificuldade que o sistema encontra frente à complexidade dos crimes apurados, mas que serve como uma estratégia de defesa, já que o acusado pretende obter favores em troca de informações, e que possui utilidade recíproca, como aponta o ministro Néfi Cordeiro. ${ }^{79}$ Em que pese a previsibilidade legal da revogação do acordo possa ensejar dúvidas quanto à constitucionalidade da renúncia ao direito ao silêncio, como demonstrado anteriormente, o cumprimento das cláusulas do acordo cabe a ambas as partes, que tiveram plena ciência das sanções impostas quando de seu descumprimento.

76 BOTTINO, Thiago. Colaboração premiada e incentivos à cooperação no processo penal: uma análise crítica dos acordos firmados na "Operação Lava Jato". Revista Brasileira de Ciências Criminais, São Paulo, v. 24, n. 122, ago. 2016, p. 10.

77 BOTTINO, Thiago. Op.cit. 2016, p. 12.

78 VASCONCELLOS, Vinicius Gomes de. Op.cit. 2017, p. 167.

79 CORDEIRO, Néfi. Op.cit. 
Nos processos penais que tramitaram nos Tribunais da Inquisição, a Igreja Católica (investida no papel do Estado) detinha todo o poder de investigação, acusação e julgamento, traçando uma abismal desigualdade na relação entre as partes, uma das principais características do sistema inquisitório. Ressalvadas as devidas proporções, os órgãos estatais que são partes no acordo de colaboração premiada possuem poder maior na negociação, gerando também uma relação desproporcional entre as partes. Verifica-se, como demonstrado a seguir, que muitos acordos foram firmados com promessas de benefícios que extrapolam os limites negociais estabelecidos em lei, tais como a previsão de penas concretas, com início do cumprimento imediato, e a implementação de regimes diferenciados, não previstos em lei.

Ainda que a maioria desses benefícios possa ser mais favorável aos acusados, a prática realizada pelo Mistério Público e corroborada pelo Poder Judiciário, rompe, em grande medida, com o respeito à legalidade e podem prejudicar o equilíbrio entre custo e benefício estabelecido pelo legislador, além de propiciar a "dissuasão para cooperações falsas ou redundantes", ${ }^{80}$ colocando em perigo a eficácia plena do instituto. Como demonstrou Bottino, ${ }^{81}$ no ano de 2014 o Ministério Público Federal firmou os primeiros acordos de colaboração premiada na Operação Lava Jato com Paulo Roberto Costa, Alberto Youssef e Pedro José Barusco Filho concedendo benefícios diversos não previstos pela Lei 12.850/2013, tais como:

a) substituição de prisão cautelar pela prisão domiciliar com uso de tornozeleira eletrônica;

b) fixação do tempo (ou intervalo de tempo) máximo de cumprimento da pena privativa de liberdade a ser cumprida em regime pré-determinado, independente das cominadas em sentença;

80 BOTTINO, Thiago. Op.cit. 2016, p. 12.

81 Idem, p. 7-8. 
c) permissão de progressão per saltum de regime diretamente do fechado para o aberto;

d) cumprimento da pena em regimes diferenciados;

e) permissão de utilização, pelos parentes do colaborador, de bens declaradamente produto de crime;

f) aplicação de multa.

0 ministro Néfi Cordeiro ${ }^{82}$ pontuou ainda vários favores oferecidos pelo Ministério Público Federal que interferem inclusive na competência de outros juízos, como a promessa de arquivamento ou suspensão de processos contra o colaborador que tramitam em varas diversas, ou até mesmo demandas contra parentes que transcendem a lide penal em questão, ou, ainda, assumindo o compromisso de não iniciar ou suspender investigações contra familiares que estejam envolvidos na organização criminosa, uma espécie de inviolabilidade de persecução antecipada. Mas a criatividade não se esgota por aí. Há diversos outros benefícios que estão sendo prometidos e que também não possuem previsão na Lei de Combate às Organizações Criminosas, bem lembrado por Vasconcellos como "a regulação de imunidade a familiares e terceiros ao acordo, a renúncia ao acesso à justiça e aos recursos e a imprecisão de um dever genérico de colaboração". 83

Segundo o princípio da legalidade, a pena cominada a determinado crime deve estar prevista expressamente em lei, ou seja, não se pode criar uma pena, ainda que seja muito melhor do que a prevista pelo legislador. Costa ressalta que, apesar da arbitrariedade que o titular da ação penal possui para negociar o acordo, a Lei 12.850/2013 é bastante restritiva no que diz respeito aos benefícios que podem ser ofertados ao colaborador:

82 CORDEIRO, Néfi. Op.cit.

83 VASCONCELLOS, Vinicius Gomes de. Op.cit. 2017, p. 147. 
Sob o ponto de vista da legalidade, a estipulação de tais cláusulas como objeto da colaboração premiada é prática condenável e deveria ser evitada. O sistema processual brasileiro, diferentemente do americano, não confere ampla discricionariedade à acusação para negociar, mas delimita as regras que devem ser seguidas para que o acordo de colaboração possa ser considerado legal, regular e voluntário. ${ }^{84}$

No mesmo sentindo, Canotilho e Brandão observam que todos os benefícios previstos na lei que tratam da colaboração premiada são taxativos e estão subordinados rigorosamente ao que reza o princípio da legalidade criminal:

Nisto vai implicada a taxatividade do catálogo legal dos benefícios que poderão ser atribuídos ao colaborador: vantagens que não se encontrem legalmente previstas não podem ser prometidas e concedidas. Não se divisando no regime legal qualquer lacuna que careça de integração, será ainda inaceitável a outorga de privilégios extralegais com base em argumentos de identidade ou maioria de razão ou em analogia. Técnicas que, aliás, sempre seriam de reputar-se como inadmissíveis num meio de obtenção de prova que contende com direitos fundamentais de terceiros como é o caso da colaboração premiada. ${ }^{85}$

Além dos exemplos acima apontados, Vasconcellos noticia a existência de acordos com "cláusulas que determinam o início do cumprimento das penas neles fixadas logo após a homologação

84 COSTA, Leonardo Dantas. Op.cit. 2017, p. 140.

85 CANOTILHO, J. J. Gomes; BRANDÃO, Nuno. Colaboração premiada e auxílio judiciário em matéria penal: a ordem pública como obstáculo à cooperação com a operação Lava Jato. Revista de Legislação e Jurisprudência. ano 146. n. 4000. p. 16-39. Coimbra: Gestlegal, set.-out. 2016, p. 30. 
judicial". ${ }^{86}$ Situação que pode beirar o absurdo para Néfi Cordeiro, ${ }^{87}$ citando o exemplo de um advogado que convenceu o seu cliente a celebrar um acordo com cumprimento imediato da pena e em regime diferenciado (em sua casa) sob a argumentação de que tal sanção lhe era favorável, além de, ao final do processo, já ter cumprido a totalidade da pena (ou parte dela), precisa agora torcer para que seu cliente seja condenado, caso contrário terá feito um péssimo negócio. Casos como esse mostram que, por vezes, as penas acordadas podem ser mais severas do que a própria condenação ou, ainda "pior", situações passíveis de absolvição. Semelhante ao que comumente acontecia nos Tribunais da Inquisição em que "em alguns casos a pena era de menor gravidade que as torturas sofridas". ${ }^{88}$

Além de ilegal, Canotilho e Brandão ${ }^{89}$ afirmam que tal circunstância é inconstitucional. Com efeito, o artigo $5^{\circ}$, inciso LIV, da Constituição Federal veda a execução da pena criminal sem um prévio e devido processo legal. Desse modo, o benefício ofertado que determina o imediato cumprimento da pena sem uma sentença penal condenatória não pode ser aceito em um Estado democrático de direito. Os autores ressaltam ainda que tal situação fere inclusive o princípio constitucional da presunção de inocência, basilar do sistema acusatório, previsto no artigo 5ํㅜ, inciso LVII, da Carta Magna. Ademais, poder-se-ia chegar ao ponto de um órgão estatal não legitimado impor penas a pessoas sem que tenham sido sequer processadas ou investigadas.

A relação desproporcional entre os órgãos estatais e o colaborador é outro ponto que gera um espaço enorme de incertezas e risco de surpresas, como bem lembra Costa. ${ }^{90}$ Quanto ao desequilíbrio da balança entre os atores processuais, Vasconcellos

\footnotetext{
86 VASCONCELLOS, Vinicius Gomes de. Op.cit. 2017, p. 173.

87 CORDEIRO, Néfi. Op.cit.

88 LOPES JR., Aury; Op.cit. 2015, p. 149.

89 CANOTILHO, J. J. Gomes; BRANDÃo, Nuno. Op.cit. 2017, p. 159-160.

90 COSTA, Leonardo Dantas. Op.cit. 2017. p. 101-102.
} 
aponta uma crítica ao que ele chama de um "sistema hipócrita de justiça",91 uma vez que considera que o modelo negocial de justiça criminal acarreta em uma hipervalorização da atuação do Ministério Público, já que extrapola o papel de acusador e assume também o de julgador na medida em que "a decisão acerca da pertinência do processo, da culpabilidade do acusado e da sanção penal a ser imposta se determina fundamentalmente pela opinião do promotor". ${ }^{92}$

Posição divergente de Costa, ${ }^{93}$ que entende que o parquet não assume funções propriamente julgadoras, pois o acordo é submetido ao Poder Judiciário quando realiza o controle de legalidade, ainda que possua uma grande vantagem sobre o colaborador, por ter todas as informações processuais sob o seu domínio em razão de ser um ente estatal. Tal entendimento converge com a posição do ministro Néfi Cordeiro, ${ }^{94}$ que agrega que é necessário haver um controle interno, uma limitação dos poderes tanto do Ministério Público como do Poder Judiciário, já que responsável pela homologação dos acordos.

É inegável que cabe ao juiz o dever de individualizar a pena, conforme previsto no artigo 59 do Código Penal. 0 ministro Ricardo Lewandowski, ${ }^{95}$ quando indeferiu um pedido de homologação do acordo de colaboração premiada por conter cláusulas não previstas na Lei 12.850/2013, ressaltou que o Poder Judiciário é quem detém o monopólio da jurisdição, sendo incabível a fixação ou o perdão de penas privativas de liberdade relativa a qualquer jurisdicionado por outro órgão que não o magistrado competente. Atitude contrária corresponderia a permitir que o Ministério Público agisse como legislador e julgador. Circunstância que retoma

91 VASCONCELLOS, Vinicius Gomes de. Op.cit. 2015, p. 180.

92 Idem, p. 182.

93 COSTA, Leonardo Dantas. Op.cit. 2017. p. 120-121.

94 CORDEIRO, Néfi. Op.cit.

95 STF. Petição. Pet 7.265/DF. Relator: Ministro Ricardo Lewandowski, julgado em 14 de novembro de 2017, p. 21-23. 
as características principais do sistema inquisitorial: o acúmulo das funções de acusação, julgamento e punição no mesmo órgão.

Contudo, em que pese a referida decisão monocrática tenha delimitado, de certa forma, os poderes do ente ministerial, o tema ainda não teve um enfrentamento direto pela suprema corte de maneira a vincular às demais decisões. Como visto, a criatividade nos acordos que vêm sendo feitos até então é imensa, por isso há a necessidade de uma maior regulamentação ou de um controle interno efetivo dos próprios órgãos estatais, já que, na maioria das vezes, os juízes não analisam de forma tão minuciosa as cláusulas do acordo, como bem fez o ministro na decisão acima mencionada. Além disso, tais acordos estão sendo celebrados isoladamente por todo o país, sem que se saiba em que termos, relativizando inclusive a segurança jurídica.

Cabe aqui destacar, como bem lembra Costa, ${ }^{96}$ que antes do advento da Lei 12.850/2013, a delação premiada era tratada como se acordo fosse (embora, como já referido anteriormente, possui natureza de direito material) e o Judiciário assumia o papel de protagonista em toda a negociação, sem qualquer intervenção do Ministério Público. Invertendo-se o cenário, a mentalidade dos operadores forenses deve ser adequada à nova realidade da colaboração premiada. Sobre o assunto, Rosa adverte:

O problema é que, como veremos, na cooperação premiada à brasileira, o juiz pode confundir seus papéis e funções, em um "mix" de atividades inconciliáveis democraticamente, especialmente quando participa do jogo oculto de se alinhar ao acusador mediante o deferimento combinado de cautelares (prisão, condução coercitiva, sequestro, interceptações, etc.). São táticas cautelares utilizadas com a intenção de aniquilar patrimonialmente os investigados/acusados, especialmente em casos de grande repercussão, mediante a imobilização

96 COSTA, Leonardo Dantas. Op.cit. 2017, p. 147-148. 
de patrimônio e, talvez, servir como trunfo para o 'forçamento' de colaboração/delação premiada. ${ }^{97}$

Assim, o último ponto que merece atenção nos acordos de colaboração premiada que estão sendo firmados no âmbito da Operação Lava Jato, que se tornou uma das mais importantes já realizadas no Brasil quando se trata de crimes de corrupção e lavagem de dinheiro, é a influência da medida cautelar da prisão preventiva na tomada da decisão do acusado em colaborar com a justiça. Assim como era regra nos Tribunais da Inquisição, para alguns doutrinadores tal medida é uma forma de arrancar a confissão do acusado. Torna-se conveniente manter o pretenso colaborador na prisão por algum tempo com o intuito de pressionar uma suposta vontade de celebração do acordo, como uma espécie de tortura psicológica.

Inicialmente, cabe referir que a doutrina diverge quanto à possibilidade de celebração de acordo de colaboração premiada com réu preso. Há quem entenda, como Costa, ${ }^{98}$ que não se deve impedir que o réu preso possa propor ou aceitar um acordo de colaboração premiada, por considerar uma afronta aos direitos de defesa do acusado, além de ferir o princípio da igualdade. Entretanto o autor pondera que a prisão não pode ser uma tática de convencimento para um pretenso colaborador.

Cabe aqui destacar o primeiro acordo realizado pela força tarefa do Ministério Público Federal com o ex-diretor da Petrobrás, Paulo Roberto da Costa, que, conforme amplamente divulgado pela mídia, inclusive pelo próprio site do Ministério Público Federal, ${ }^{99}$ teve sua primeira prisão preventiva decretada em março de 2014. Em maio do mesmo ano o STF determinou sua soltura e, no mês seguinte, após constatação de risco de fuga do país, Paulo Roberto da Costa foi novamente preso preventivamente.

97 ROSA, Alexandre Morais da. Op.cit. 2018, p. 150.

98 COSTA, Leonardo Dantas. Op.cit. 2017. p. 195.

99 BRASIL. Ministério Público Federal. A Lava Jato em números no Paraná. Disponível em: <http://www.mpf.mp.br/para-o-cidadao/caso-lava-jato/ atuacao-na-1a-instancia/parana/resultado>. Acesso em: 08 nov. 2018. 
O acordo de colaboração premiada foi celebrado em agosto de 2014. Há outro exemplo dentro da mesma força-tarefa em que Marcelo Odebrecht, preso preventivamente em junho de 2015 e condenado em primeira instância em março de 2016, teve seu pedido de habeas corpus negado pelo STF em 22 de novembro de 2016 (HC 132.267/PR) e, em 1o de dezembro de 2016, portanto, 9 (nove) dias após a denegação da ordem, selou acordo de colaboração premiada. Impende ressaltar que não serão consideradas as ponderações dos julgados, do ponto de vista meritório de um e de outro caso, mesmo porque a análise é feita no caso concreto, cada um suas particularidades atendendo ou não aos requisitos legais acerca das possibilidades da prisão preventiva, mas, sim, em que medida a manutenção da prisão preventiva pode influenciar as decisões de cooperar com a justiça.

O ministro Teori Zavascki, quando do julgamento do HC 127.186/PR, ressaltou que a manutenção do acusado em prisão preventiva como forma de extrair do mesmo uma colaboração premiada seria extremamente arbitrária uma vez que, conforme artigo $4^{\circ}$, caput e $\S^{0}$ ㅇ da Lei $12.850 / 2013$, a mesma deve ser voluntária. 0 magistrado ainda complementa:

Subterfúgio dessa natureza, além de atentatório aos mais fundamentais direitos consagrados na Constituição, constituiria medida medievalesca que cobriria de vergonha qualquer sociedade civilizada. ${ }^{100}$

Quando Rosa ${ }^{101}$ analisa a delação premiada através da teoria dos jogos, ${ }^{102}$ ele observa que a presunção da autonomia da vonta-

100 STF. Habeas Corpus. HC 127.186/PR. Relator: Ministro Teori Zavascki, 2aㅡ Turma, julgado em 28.04.2015, p. 18.

101 ROSA, Alexandre Morais da. Op.cit. 2018, p. 264.

102 Alexandre Morais da Rosa analisa o processo penal sob o ponto de vista da "teoria dos jogos". Por essa analogia, as partes são vistas como jogadores, que utilizam estratégias e táticas, assim como em um jogo, que determinam seu resultado final, frente ao ambiente de instabilidade que o processo penal enfrenta atualmente. Cf. ROSA, Alexandre Morais da. Guia compacto do processo penal conforme a teoria dos jogos. 3 ed. Florianópolis: Empório do Direito, 2016. 
de deve ser moderada quando o colaborador ou seus familiares estiverem submetidos ou ameaçados por medidas cautelares, como é o caso da prisão preventiva. 0 modo como o acusado manifesta sua vontade é afetado pela escassez de liberdade. 0 autor aponta, ainda, que "a prisão cautelar ou a condução coercitiva podem servir para criação artificial de ambiente para incidência do dilema do prisioneiro" 103 em cooperar ou não.

Costa ${ }^{104}$ pondera que a restrição da liberdade física do acusado, como a prisão preventiva, não vicia, por si só, a voluntariedade do ato de colaborar, na medida em que a sua liberdade psíquica permanece preservada. Contudo, reconhece que a prisão preventiva utilizada com viés utilitarista, configura-se como "verdadeiras táticas de aniquilação cujo objetivo é servir de elemento de convencimento do imputado em colaborar com a Justiça", ${ }^{105}$ forçando uma cooperação, uma vez que a liberdade é empregada como um prêmio àquele que se mostra disposto a colaborar. Ressalta, ainda, que, aliado às táticas do uso da prisão cautelar, o controle das informações estatais "pode influenciar na formação da vontade do colaborador". ${ }^{106}$

No mesmo sentido, Rosa ${ }^{107}$ afirma que o uso da prisão temporária possui o poder de desestabilizar o acusado podendo funcionar ainda como tática de emboscada para a delação, na medida em que a pressão e o desgaste psicológico, sobretudo se envolver familiares, torna-o mais suscetível à cooperação, podendo promover ou incentivar confissões ou colaborações, que talvez não fossem alvo de acordo se o mesmo estivesse em liberdade. 0 autor destaca ainda que a resposta estatal para aqueles que não estão dispostos a colaborar com a Justiça, acabam servindo de "exemplo" para os demais investigados. Exemplifica tal ponto com o caso de Marcelo Odebrecht:

\footnotetext{
103 ROSA, Alexandre Morais da. Op.cit. 2018, p. 83.

104 COSTA, Leonardo Dantas. Op.cit. 2017, p. 175.

105 COSTA, Leonardo Dantas. Op.cit. 2017, p. 176.

106 Idem, p. 183.

107 ROSA, Alexandre Morais da. Op.cit. 2018, p. 266-269.
} 
Pode-se supor, por exemplo, no âmbito da Lava jato, que quando Marcelo Odebrecht não aceitou a colaboração premiada, logo se iniciou a instrução processual. Com isso, ao final, diante da pena aplicada, bens sequestrados e massacres midiáticos, inclusive à família, as resistências foram amplamente reduzidas. A tática de choque com Marcelo Odebrecht serviu, também, aos demais investigados como "exemplo", a saber, sairá caro para quem não cooperar. 0 peso da resposta estatal esmaga a resistência e incentiva à colaboração premiada, como, de fato, operou-se. ${ }^{108}$

Tendo como pano de fundo os exemplos de Paulo Roberto da Costa e Marcelo Odebrecht, é possível fazer um paralelo acerca do destaque acima apontado por Alexandre Morais da Rosa sobre a utilização do poder estatal como forma de exemplo para os demais acusados, ou, ainda, para com a sociedade, com as práticas inquisitoriais. Da mesma forma, o sistema inquisitorial utilizava-se do poder estatal para amedrontar aqueles que haviam cometido crimes de heresia, sinalizando as sanções que poderiam sofrer caso não confessassem seus crimes.

No âmbito da Operação Lava Jato, Néfi Cordeiro ${ }^{109}$ aponta que o Ministério Público Federal diz ter estatísticas que comprovam que a maior parte dos acordos é feita com pessoas em liberdade. Em contraponto, Toron analisa que "a Operação Lava Jato só conseguiu o êxito marcante nas investigações mediante a utilização desmedida e prolongada de prisões preventivas, que levaram a um elevado número de delações premiada". ${ }^{110}$

Tais conclusões demonstram que o atual uso do instituto da colaboração premiada não está em consonância com os direitos e garantias dos acusados atinentes ao sistema acusatório e pre-

108 Idem, p. 267.

109 CORDEIRO, Néfi. Op.cit.

110 TORON, Alberto Zacharias. 0 direito de defesa na Lava Jato. Revista Brasileira de Ciências Criminais. v. 122. São Paulo: RT, ago. 2016, p. 1. 
vistos na Constituição Federal de 1988. O que resta evidenciado que o instituto da colaboração premiada resgatou traços do autoritarismo do sistema inquisitivo.

\section{CONSIDERAÇÕES FINAIS}

É notório que a justiça negocial criminal é uma tendência mundial nos países democráticos que se justifica por ser um meio altamente eficaz na busca pela eficiência e celeridade da persecução penal. 0 instituto da colaboração premiada acaba sendo um estímulo, dado pelo Estado, que reduz, em muito, as diligências necessárias em busca da resolução dos delitos.

0 instituto da colaboração premiada, previsto na Lei 12.850/13, é, sem dúvida, um avanço introduzido no ordenamento jurídico na medida em que prevê maior segurança para as partes, tornando mais confiável e previsível a benesse a ser obtida após a efetivação do instrumento premial, além de conferir maior celeridade e eficiência na persecução penal na busca pelo desmantelamento de organizações criminosas complexas. Contudo, há ainda alguns aspectos relevantes que restaram omissos na legislação e que devem ser sanados para evitar abusos em sua aplicação e situações contraditórias com o sistema acusatório.

Em que pese a referida lei tenha sido introduzida no ordenamento jurídico prevendo regras gerais processuais do acordo de colaboração premiada, como amplamente abordado, a prática nem sempre parece corresponder à expectativa do legislador, seja por lacunas existentes na própria lei, seja na forma de interpretação dos operadores dos órgãos públicos que, por terem a prerrogativa de atuarem em nome do Estado e sob a justificativa da necessidade de uma resposta à sociedade frente à sensação de impunidade existente, principalmente quando se trata de crimes de corrupção envolvendo importantes nomes no cenário político e econômico, cometem atos não previstos em lei ou em desconformidade com direitos e princípios democráticos. Tais violações 
acabam representando o retorno do legado inquisitorial, porém sob outros discursos justificadores.

As evidências demonstram que sem os acordos de colaboração premiada firmados na Operação Lava Jato não se teria alcançado a devolução aos cofres públicos de monta que atualmente ultrapassa a casa dos bilhões de reais, ${ }^{111}$ o que é altamente louvável. Entretanto, há a necessidade de limitar algumas práticas a fim de garantir a utilidade recíproca do instituto. Do mesmo modo que não se pode propiciar um ambiente em que os benefícios ofertados sejam tão grandes que qualquer pessoa, em situação semelhante, confessar-se-ia culpada diante de um crime que não cometeu, não se pode privá-la de sua liberdade, torturando-a psicologicamente, apenas para que se renda aos anseios dos órgãos estatais frente a sua incapacidade persecutória, semelhante ao que ocorria durante a época em que imperava o sistema inquisitivo.

Não é admissível que manobras desse tipo sejam usadas facilmente pelos órgãos estatais com os mesmos objetivos e mesmas relativizações que remontam à mentalidade do sistema inquisitorial, em pleno século XXI em um Estado democrático de direito. Se a colaboração premiada deve ser mantida no ordenamento jurídico, ela precisa observar os impactos de seu emprego na vida do colaborador. É necessário criar barreiras nesse tipo de mecanismo para que restem assegurados os direitos e garantias fundamentais constitucionais dos cidadãos, além dos princípios e diretrizes das leis processuais penais brasileiras.

0 que resta claro é que o instituto da colaboração premiada acaba sendo um momento de grande importância no decorrer do processo, porém não como oportunidade de defesa do imputado, mas como forma de desvelar outros crimes (sobretudo seus auto-

111 BRASIL. Ministério Público Federal. A Lava Jato em números no Paraná. Disponível em: <http://www.mpf.mp.br/para-o-cidadao/caso-lava-jato/ atuacao-na-1a-instancia/parana/resultado>. Acesso em: 08 nov. 2018. 
res) além dos já conhecidos, do mesmo modo como era a delação nos Tribunais da Inquisição. Por todo o exposto, corrobora-se a tese de que o instituto da colaboração premiada, da forma como está sendo utilizado em muitos casos, é marcado pelo legado do sistema penal inquisitorial, em que os fins justificam os meios, ferindo os princípios basilares de um Estado democrático de direito.

\section{REFERÊNCIAS}

BECCARIA, Cesare. Dos delitos e das penas. São Paulo: Martin Fontes, 1997. (Coleção Clássicos).

BOTTINO, Thiago. Colaboração premiada e incentivos à cooperação no processo penal: uma análise crítica dos acordos firmados na "Operação Lava Jato". Revista Brasileira de Ciências Criminais. v. 122. São Paulo: RT, ago. 2016.

BRASIL. Decreto-lei no 2.848, de 7 de dezembro de 1940. Código Penal. Rio de Janeiro, 1940. Disponível em: <http://www.planalto.gov. br/ccivil_03/decreto-lei/del2848.htm>. Acesso em 08 nov. 2018.

BRASIL. Lei no 7.492, de 16 de junho de 1986. Define os crimes contra o sistema financeiro nacional. Brasília, 1986. Disponível em: <http://www.planalto.gov.br/ccivil_03/leis/L7492.htm>. Acesso em 08 nov. 2018.

BRASIL. Constituição da República Federativa do Brasil de 1988. Brasília, 1988. Disponível em: <http://www.planalto.gov.br/ccivil_03/ constituicao/constituicaocompil ado.htm>. Acesso em 08 nov. 2018.

BRASIL. Lei no 8.072, de 25 de julho de 1990. Dispõe sobre os crimes Hediondos. Brasília, 1990. Disponível em: <http://www.planalto.gov. br/ccivil_03/L eis/L8072com pilada.htm>. Acesso em 08 nov. 2018.

BRASIL. Lei no 8.137, de 27 de dezembro de 1990. Define crimes contra a ordem tributária, econômica e contra as relações de consumo. Brasília, 1990. Disponível em: <http://www.planalto.gov.br/ccivil_03/ LEIS/L8137.htm>. Acesso em 08 nov. 2018.

BRASIL. Lei no 9.034, de 03 de maio de 1995. Dispõe sobre a utilização de meios operacionais para a prevenção e repressão de ações praticadas por organizações criminosas. Brasília, 1995. Disponível em: <http://www.planalto.gov.br/cCivil_03/LEIS/L9034.htm>. Acesso em 08 nov. 2018. 
BRASIL. Lei no 9.080, de 19 de julho de 1995. Acrescenta dispositivos às Leis no 7.492, de 16 de junho de 1986, e 8.137, de 27 de dezembro de 1990. Brasília, 1995. Disponível em: <http://www.planalto.gov.br/ ccivil_03/LEIS/L9080.htm>. Acesso em 08 nov. 2018.

BRASIL. Lei no 9.269, de 02 de abril de 1996. Dá nova redação ao $\S 4^{\circ}$ do art. 159 do Código Penal. Brasília, 1996. Disponível em: <http://www. planalto.gov.br/ccivil_03/LEIS/L9269.htm>. Acesso em 08 nov. 2018.

BRASIL. Lei no 9.613, de 03 de março de 1998. Dispõe sobre os crimes de "lavagem" ou ocultação de bens, direitos e valores; a prevenção da utilização do sistema financeiro para os ilícitos previstos nesta Lei; cria o Conselho de Controle de Atividades Financeiras - COAF. Brasília, 1998. Disponível em: <http://www.planalto.gov.br/ccivil_03/LEIS/ L9613.htm>. Acesso em 08 nov. 2018.

BRASIL. Lei no 9.807, de 13 de julho de 1999. Estabelece normas para a organização e a manutenção de programas especiais de proteção a vítimas e a testemunhas ameaçadas, institui o Programa Federal de Assistência a Vítimas e a Testemunhas Ameaçadas e dispõe sobre a proteção de acusados ou condenados que tenham voluntariamente prestado efetiva colaboração à investigação policial e ao processo criminal. Brasília, 1999. Disponível em: <http://www.planalto.gov.br/ccivil_03/ LEIS/L9807.htm>. Acesso em 08 nov. 2018.

BRASIL. Lei no 12.850, de 02 de agosto de 2013. Define organização criminosa e dispõe sobre a investigação criminal, os meios de obtenção da prova, infrações penais correlatas e o procedimento criminal. Brasília, 2013. Disponível em: <http://www.planalto.gov.br/ccivil_03/_ato20112014/2013/lei/l12850.htm>. Acesso em 08 nov. 2018.

BRASIL. Ministério Público Federal. A Lava Jato em números no Paraná. Disponível em: <http://www.mpf.mp.br/para-o-cidadao/caso-lava-jato/ atuacao-na-1a-instancia/atuacao-na-1a-instancia/parana/resultado $>$. Acesso em 08 nov. 2018.

CANOTILHO, J. J. Gomes; BRANDÃO, Nuno. Colaboração premiada e auxílio judiciário em matéria penal: a ordem pública como obstáculo à cooperação com a operação Lava Jato. Revista de Legislação e Jurisprudência. ano 146. n. 4000. p. 16-39. Coimbra: Gestlegal, set.-out. 2016.

Colaboração Premiada: reflexões críticas sobre os acordos fundantes da Operação Lava Jato. Revista Brasileira de Ciências Criminais. São Paulo, v. 133. p. 133-171, jul. 2017. 
CARVAlHO, Salo de. Pena e Garantias. 3. ed. rev. atual. Rio de Janeiro: Lumen Juris, 2008.

CHOUKR, Fauzi Hassan. Código de processo penal: comentários consolidados e crítica jurisprudencial. Rio de Janeiro: Lumen Juris, 2010.

CORDEIRO, Néfi. Controle Judicial de Colaboração Premiada. Porto Alegre, Tribunal Regional Federal da 4⿳亠丷a Região, 24 set. 2018. Conferência destinada aos magistrados federais da 4 a região, servidores, convidados e estagiários da corte.

COSTA, Leonardo Dantas. Delação premiada: a atuação do Estado e a relevância da voluntariedade do colaborador com a justiça. Curitiba: Juruá, 2017.

EYMERICH, Nicolau; PEÑA, Francisco. Manual dos Inquisidores. Rio de Janeiro: Rosa dos Tempos, 1993.

KHALED JR., Salah H. A busca da verdade no processo penal: para além da ambição inquisitorial. 2. ed. Belo Horizonte, MG: Letramento: Casa do Direito, 2016.

KRAMER, Heinrich; SPRENGER, James. 0 martelo das feiticeiras: malleus maleficarum. 12. ed. Rio de Janeiro: Rosa dos Tempos, 1997.

LOPES JR., Aury. Direito Processual Penal e sua Conformidade Constitucional. v. 1. 3. ed. rev. atual. Rio de Janeiro: Lumen Juris, 2008.

. Fundamentos do processo penal: introdução crítica. São Paulo: Saraiva, 2015.

MARCÃO, Renato. Curso de processo penal. 4. ed. rev. ampl. atual. São Paulo: Saraiva Educação, 2018.

MARQUES, José Frederico. Elementos de direito processual penal. v. 1. 2. ed. Campinas: Millennium, 2000.

MENDONÇA, Andrey Borges de. Os benefícios possíveis na colaboração premiada: entre a legalidade e a autonomia da vontade. In: BOTTINI, Pierpaolo Cruz; MOURA, Maria Thereza de Assis (coordenação). Colaboração Premiada. São Paulo: Revista dos Tribunais, 2017.

PACHECO, Denilson Feitoza. Direito processual penal: teoria, crítica e práxis. 5. ed. rev. atual. Niterói, RJ: Impetus, 2008.

ROSA, Alexandre Morais da. Guia compacto do processo penal conforme a teoria dos jogos. 3 ed. Florianópolis: Empório do Direito, 2016. 
Para entender a delação premiada pela teoria dos jogos: táticas e estratégias no negócio jurídico. Florianópolis: EModara, 2018. SALOMI, Maíra Beauchamp. Colaboração premiada: principais questões acerca da competência para homologação. In: BOTTINI, Pierpaolo Cruz; MOURA, Maria Thereza de Assis (coord). Colaboração Premiada. São Paulo: Revista dos Tribunais, 2017.

TORON, Alberto Zacharias. 0 direito de defesa na Lava Jato. Revista Brasileira de Ciências Criminais. v. 122. São Paulo: RT, ago. 2016.

TOURINHO FILHO, Fernando da Costa. Processo penal. v. 1. 29. ed. rev. atual. São Paulo: Saraiva, 2007.

VASCONCELLOS, Vinicius Gomes de. Barganha e justiça criminal negocial: análise das tendências de expansão dos espaços de consenso no processo penal brasileiro. São Paulo: IBCCRIM, 2015.

Colaboração premiada no processo penal. São Paulo: Revista dos Tribunais, 2017. 